\title{
Conservation of soil organic carbon, biodiversity and the provision of other ecosystem services along climatic gradients in West Africa
}

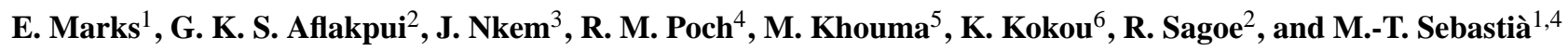 \\ ${ }^{1}$ Forest Technology Center of Catalonia (CTFC), Crta St Llorenç de Morunys km 2, 25280 Solsona, Spain \\ ${ }^{2}$ Crops Research Institute (CSIR), P.O. Box 3785, Kumasi, Ghana \\ ${ }^{3}$ Center for International Forestry (CIFOR), Situ Gede, Sindang Barang, Bogor Barat 16680, Indonesia \\ ${ }^{4}$ University of Lleida, Rovira Roure 191, 25198 Lleida, Spain \\ ${ }^{5}$ United Nations Office for Project Services (UNOPS), Regional Office for West and Central Africa, BP 15702 Dakar-Fann, \\ Dakar, Senegal \\ ${ }^{6}$ Laboratory of Botany and Ecology, Faculty of Sciences, Univ. of Lomé, BP 1515, Lomé, Togo
}

Received: 13 August 2008 - Published in Biogeosciences Discuss.: 26 November 2008

Revised: 20 March 2009 - Accepted: 21 July 2009 - Published: 31 August 2009

\begin{abstract}
Terrestrial carbon resources are major drivers of development in West Africa. The distribution of these resources co-varies with ecosystem type and rainfall along a strong Northeast-Southwest climatic gradient. Soil organic carbon, a strong indicator of soil quality, has been severely depleted in some areas by human activities, which leads to issues of soil erosion and desertification, but this trend can be altered with appropriate management. There is significant potential to enhance existing soil carbon stores in West Africa, with benefits at the global and local scale, for atmospheric $\mathrm{CO}_{2}$ mitigation as well as supporting and provisioning ecosystem services. Three key factors impacting carbon stocks are addressed in this review: climate, biotic factors, and human activities. Climate risks must be considered in a framework of global change, especially in West Africa, where landscape managers have few resources available to adapt to climatic perturbations. Among biotic factors, biodiversity conservation paired with carbon conservation may provide a pathway to sustainable development, and biodiversity conservation is also a global priority with local benefits for ecosystem resilience, biomass productivity, and provisioning services such as foodstuffs. Finally, human management has largely been responsible for reduced carbon stocks, but this trend can be reversed through the implementation of appropriate carbon conservation strategies in the agricultural sector, as shown by multiple studies. Owing to the strong regional climatic gradient, country-level initia-
\end{abstract}

Correspondence to: M.-T. Sebastià (teresa.sebastia@ctfc.cat) tives will need to consider carbon sequestration approaches for multiple ecosystem types. Given the diversity of environments, global policies must be adapted and strategies developed at the national or sub-national levels to improve carbon storage above and belowground. Initiatives of this sort must act locally at farmer scale, and focus on ecosystem services rather than on carbon sequestration solely.

\section{Introduction}

Globally, soils are major reservoirs of terrestrial carbon (C), containing an estimated mass of $1200-1600 \times 10^{9} \mathrm{Mg}$ of $\mathrm{C}$ (Eswaran et al., 1993; Batjes, 1996; Zech et al., 1997), which makes them an essential component of atmospheric $\mathrm{CO}_{2}$ mitigation. In West Africa, soil $\mathrm{C}$ is also crucial for fertilization and the prevention of erosion and desertification, particularly in drylands (Palm et al., 1997), therefore providing ecosystem services on the local as well as the global scales.

Soil C exists in two principal forms, organic (SOC) and inorganic (SIC). At a global scale the relative distribution of the forms depends strongly on climate (Table 1). In general, SOC content increases with precipitation, with optimum levels in humid and cold climates (Eswaran et al., 1999). SIC is more important in soils of arid and semiarid zones (Eswaran et al., 1999; Table 1). Whereas SOC storage is related to biophysical factors and management practices, SIC is relatively resistant to these factors.

Most soil C is found in organic form (Table 1; Eswaran et al., 1999), principally stored in the soil organic matter (SOM). SOC storage varies within regions and biomes

Published by Copernicus Publications on behalf of the European Geosciences Union. 
Table 1. SOC and SIC storage in the world. Source: summarized from Eswaran et al., 1999.

\begin{tabular}{lccccccc}
\hline Order & Area\% & \multicolumn{2}{c}{ Organic Carbon } & \multicolumn{2}{c}{ Inorganic Carbon } & \multicolumn{2}{c}{ Total Carbon } \\
\hline & & $\mathrm{Pg}$ & $\%$ & $\mathrm{Pg}$ & $\%$ & $\mathrm{Pg}$ & $\%$ \\
Gelisols & 8.6 & 316 & 20.4 & 7 & 0.8 & 323 & 12.9 \\
Histosols & 1.2 & 179 & 11.6 & 0 & 0.1 & 180 & 7.2 \\
Spodosols & 2.6 & 64 & 4.1 & 0 & 0.0 & 64 & 2.6 \\
Andisols & 0.7 & 20 & 1.3 & 0 & 0.0 & 20 & 0.8 \\
Oxisols & 7.5 & 126 & 8.1 & 0 & 0.0 & 126 & 5.1 \\
Vertisols & 2.4 & 42 & 2.7 & 21 & 2.3 & 64 & 2.6 \\
Aridisols & 12.0 & 59 & 3.8 & 456 & 48.0 & 515 & 20.6 \\
Ultisols & 8.4 & 137 & 8.8 & 0 & 0.0 & 137 & 5.5 \\
Mollisols & 6.9 & 121 & 7.8 & 116 & 12.2 & 237 & 9.5 \\
Alfisols & 9.6 & 158 & 10.2 & 43 & 4.5 & 201 & 8.0 \\
Inceptisols & 9.8 & 190 & 12.2 & 34 & 3.6 & 224 & 9.0 \\
Entisols & 16.2 & 90 & 5.8 & 263 & 27.7 & 353 & 14.2 \\
Miscellaneous & 14.1 & 24 & 1.5 & 0 & 0.0 & 24 & 1.0 \\
Total & 100.0 & 1526 & 100.0 & 940 & 100.0 & 2468 & 100.0 \\
\hline
\end{tabular}

Table 2. Carbon stocks and other fertility indicators of granitic soils in different agro-ecological zones in West Africa spanning the N-S climatic gradient. Source: Bationo et al., 2007.

\begin{tabular}{lcccc}
\hline Agro-ecological zone & $\mathrm{pH}\left(\mathrm{H}_{2} \mathrm{O}\right)$ & $\mathrm{OC}\left(\mathrm{g} \mathrm{kg}^{-1}\right)$ & Total $\mathrm{N}\left(\mathrm{g} \mathrm{kg}^{-1}\right)$ & Total P $\left(\mathrm{mg} \mathrm{kg}^{-1}\right)$ \\
\hline Equatorial forest & 5.3 & 24.5 & 1.6 & 628 \\
Guinea savannah & 5.7 & 11.7 & 1.39 & 392 \\
Sudan savannah & 6.8 & 3.3 & 0.49 & 287 \\
\hline
\end{tabular}

(Table 2). Three major climatic and vegetational zones can be broadly distinguished in West Africa, from South to North and from the coastal to inland areas, designated as the Guinean (humid forest), Sudanian (savannah), and Sahelian (desert and semi-desert) zones (White, 1983), and SOC varies considerably across these zones (Table 2). Vegetation distribution matches the strong climatic gradient, from the humid Guinean forests in the coastal south-western areas, through the savannahs in the semi-arid intermediate belt, into the desert and semi-desert inner continental areas. The transition between semi-deciduous forests and savannahs also represents an interaction between climate, biota and human activities (Latham et al., 1970; Jordan, 1983; Jenik, 1994) along the climate-driven soil fertility gradient (Table 2).

In addition to SOM formation, SOC storage depends on SOC stabilization. Processes driving SOC stabilization can be abiotic, including those directly or indirectly depending on temperature and precipitation, or biotic, including productivity and organic matter decomposition (Trumbore, 1997; Thornley and Cannell, 2001; Schulze, 2006). SOC accumulation can also be modified through management. In West Africa, Hien et al. (2006) found $61 \mathrm{Mg} \mathrm{Cha}^{-1}$ under natural savannah, $25 \mathrm{Mg} \mathrm{Cha}^{-1}$ under crops amended with organic manure, and $16 \mathrm{Mg} \mathrm{Cha}^{-1}$ under unmanured crops within a depth of $30 \mathrm{~cm}$.
The West African region is heavily dependent on climatesensitive sectors like agriculture, pastoral practices, forestry, fisheries, etc. These sectors are also C-based systems, emphasizing the pivotal role of both above and belowground $\mathrm{C}$ in the provisioning of ecosystem goods and services. SOC in various pools (either in plant biomass, litter or soil) constitutes a major driver of development in West Africa, and underlies major ecosystem services such as nutrient and soil moisture retention that contribute to plant productivity (Fischer et al., 2006).

The dynamic connection between soil resources and household livelihood could be viewed through food insecurity that also contributes to the vulnerability of West Africa to climate impacts according to the IPCC fourth assessment report (IPCC, 2007b). Africa has continuously experienced declining agricultural productivity per head that stands at $0.4 \%$ between 2000 and 2004 (UNEP, 2007). This limits the realization of the Millennium Development Goal (MDG 1; Millennium Ecosystem Assessment, 2005). Decline in soil productivity is invariably linked to changes in the SOM pools that prevail in West Africa with increasing human activities of land transformation, especially under increasing population. Lui et al. (2004) highlighted the trend of decreasing total $\mathrm{C}$ stocks both in vegetation and soils, and predicted that this will continue through the 21 st century unless measures 
Table 3. Potential of the West Africa North Africa (WANA) region (Lal, 2002) and the global dryland systems to sequester C under various strategies. Source: Lal, 2002.

\begin{tabular}{lcc}
\hline & West Africa and North Africa region & Global dryland system \\
\hline Strategy & $\left(\mathrm{Tg} \mathrm{C} \mathrm{yr}^{-1}\right)$ & $($ Tg C yr-1) \\
Desertification Control & $40-100$ & $200-300$ \\
Reclamation of salt-affected lands & $9-18$ & $200-400$ \\
Agricultural intensification on undegraded soils & $6-12$ & $10-20$ \\
Fuel C offset & $88-175$ & $300-500$ \\
Soil C sequestration under biofuel planting & $25-75$ & NA \\
Total & $168-380$ & $710-1220$ \\
\hline
\end{tabular}

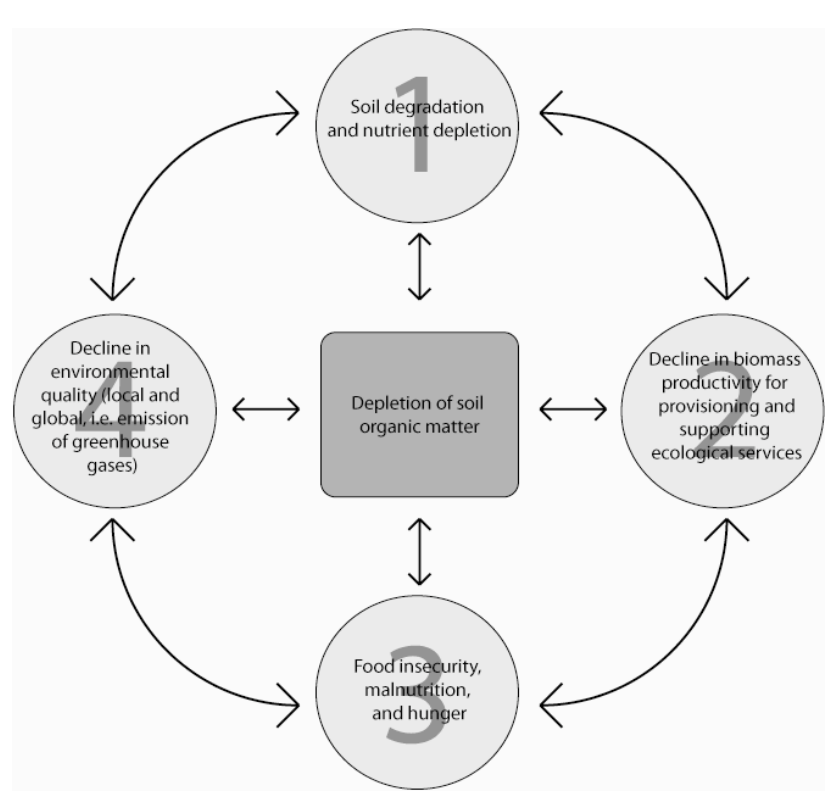

Fig. 1. Diagram showing the cycle associated with soil carbon depletion witnessed in African cereal farming systems. Soil carbon depletion impacts: 1) soil fertility, 2) ecological services, 3) food security with impacts on livelihood, and 4) environmental quality and safety. The cycle can be broken by improving soil fertility by enhancing the soil organic matter pool using sustainable technologies for improved management of water and nutrients, including no-till farming, composts, mulching, cover crops, water harvesting, and agroforestry. Modified from Lal, 2004.

practices are put in place. In many cases soil mining and agriculture expansion into marginal areas as a result of increasing land pressures in West Africa have both depleted soils of their $\mathrm{C}$ and nutrients and led to erosion (Bationo et al., 2007; Fig. 1). Appropriate land use management can reverse this trend and lead to substantial storage of $\mathrm{C}$ in soils, hence contributing to ecosystem fertility but also greenhouse gas mitigation (Table 3). If management (including desertification control) were enacted, the contribution to $\mathrm{C}$ seques- tration in the West and North African region is estimated to be $23-31 \%$ of the total potential for all global drylands (Lal, 2002).

In this review we discuss the importance of SOC in West Africa for climate change mitigation and conservation of soil fertility. These two goals, along with others, may be compatible in some forestry or agriculture applications in West Africa, and we show that temporal $\mathrm{C}$ dynamics and sequestration capacity will differ between systems. We also present key climatic, biotic, and human-derived drivers of soil $\mathrm{C}$ in the region, and we give particular consideration to the role of biodiversity in $\mathrm{C}$ storage because of the potential complementarity between $\mathrm{C}$ sequestration and biodiversity conservation. Finally we discuss patterns of land use and management, and how social structures may affect the accumulation of SOC. Overall, this synthesis is aimed towards identifying the processes that have the greatest effect on soil $\mathrm{C}$-based ecosystem service provision, and how increased soil $\mathrm{C}$ sequestration might be achieved to assist both local sustainability and climate change mitigation (Fig. 2).

\section{Global relevance - climate change mitigation and the carbon cycle}

\subsection{Climate changes and soil $\mathrm{C}$ release in Africa}

New research on climate-biosphere interactions and feedback effects on the terrestrial $\mathrm{C}$ cycle is emerging from Africa (this special issue) in the form of the CARBOAFRICA project. Through comparison of different climate- $\mathrm{CO}_{2}$ circulation models (Friedlingstein et al., 2008), it appears that under anticipated climate change regimes West Africa will experience losses of Net Ecosystem Productivity (NEP) as a result of reduced precipitation, and reduction of soil $\mathrm{C}$ stores through increased heterotrophic activity due to temperature. Warming and wetting of a very limited portion of the West African coastal tropical region is expected to increase overall gross primary production for tropical forests, but the net prediction, nonetheless, is a soil $\mathrm{C}$ loss of $-100-2000 \mathrm{~g} \mathrm{C} \mathrm{m}^{-2}$ 


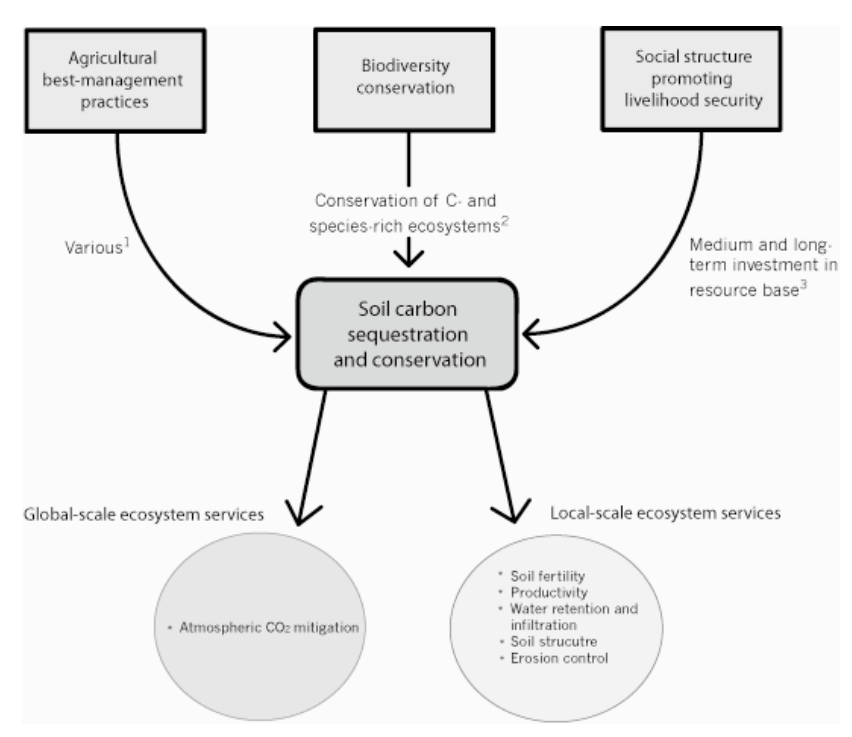

Fig. 2. Conceptual diagram of three factors of high importance which can positively influence carbon sequestration in West Africa, promoting ecosystem service provision at the global and local scales. 1: Agricultural best practices may vary depending on ecosystem type or environmental conditions, but commonlydiscussed practices to preserve soil $\mathrm{C}$ include erosion control, conservation tillage, improved fallow systems, and integration of manure or crop residues. 2: Pairing biodiversity conservation with $\mathrm{C}$ conservation initiatives may be possible in tropical zones with high biodiversity. 3: Social factors influence a smallholder's ability to invest labour and resources in C-conservation or sequestration.

as estimated to the year 2090. This may translate into losses of $13-22 \%$ in of total soil C tropical forest zones such as the Senegal River valley, and up to $16 \%$ for savannah ecosystems (Hien et al., 2006; Woomer et al., 2004a).

While precipitation losses are expected in West Africa ecosystems, the distribution and magnitude of these changes remain unclear. Following the aforementioned study by Frieldingstein and colleagues, predictions using the IPSL-CM4-LOOP model predict severe precipitation losses $\left(-100-200 \mathrm{~mm} \mathrm{yr}^{-1}\right)$ in the savannah regions with decreasing effect northward towards the Sahel, whereas predictions using the IMOGEN model have precipitation losses localized more to North-West including Northern Senegal, Mauritania and Mali, and rainfall increases in the savannah regions. Soil $\mathrm{C}$ losses and heterotrophic respiration will be greatest in the tropical regions, decreasing northward towards the Sahel.

It must be recognized that, while large scale modeling exercises can help predict general trends especially at the continent scale, temperature and precipitation alone are not the only factors affecting decomposition rates of SOC (Giardina and Ryan, 2000). Other factors, such as soil clay content, available moisture, and $\mathrm{C}$ quality may intercede against increases in decomposition promoted by higher temperatures. Methane and $\mathrm{CO}_{2}$ emission measurements in Burkina Faso show that soils under natural savannahs are net sources of $\mathrm{CH}_{4}$, which is attributed to local waterlogging; whilst croplands act as marginal $\mathrm{CH}_{4}$ sinks. Termite activity increased the $\mathrm{CH}_{4}$ emissions in two orders of magnitude (Brümmer et al., 2009). Since termite mounds are eliminated in croplands, the conversion of natural savannah to agricultural land implies a reduction of $\mathrm{C}$ release from the soil (Brümmer et al., 2009), and a higher mitigation potential, since $\mathrm{CH}_{4}$ has a 25 times higher global warming potential than $\mathrm{CO}_{2}$. There are other local factors, such as litter quality, evaluated for example by lignin content, that vary between ecosystem types, so estimations must take place at the ecosystem level, and caution must be taken in "scaling up" to the biome or landscape (Rustad et al., 2001).

In summary, with appreciation for the preliminary and generalized nature of the above conclusions, what should be noted from climate predictions is differing susceptibility of forest and savannah ecosystems to soil C loss, which generally translates to decreasing susceptibility from the West African coast inland and northward. What remains to be seen is how management may be able to decrease susceptibility to temperature changes, including more research on the factors limiting microbial communities responsible for $\mathrm{C}$ oxidation.

\subsection{Contribution to mitigation of global warming}

Between 2000 and 2006, fossil fuel emission has increased globally by $3.3 \% \mathrm{yr}^{-1}$. In $2004,73 \%$ of global emissions growth was accounted for by the developing and leastdeveloped economies (Raupach et al., 2007). However, the regional per-capita emissions and per-capita primary energy consumption of most West African countries are 1/10 of the global average (Raupach et al., 2007). The difference offers the opportunity for a different development model in the region. Climate change mitigation is a shared responsibility, and West Africa is one of the most vulnerable areas (Niasse et al., 2004).

Greenhouse gas (GHG) emission from soils is linked to soil degradation (Lal and Bruce, 1999). Soil C loss through soil erosion, in combination with mineralization of the dislodged $\mathrm{C}$ is estimated to be $4-6 \mathrm{Pg} \mathrm{yr}^{-1}$, with mineralization accounting for $20 \%$ of the erosion-induced emissions (Lal, 2003). The semi-arid and sub-humid regions of Africa have the highest potential for $\mathrm{C}$ sequestration in the world but the soils are severely degraded. West Africa holds significant amounts of SOC, about 4.2-4.5 $\mathrm{kg} \mathrm{C} \mathrm{m}^{-2}$ (Batjes, 2001), but contributed more than $50 \%$ of the net emission of $\mathrm{C}$ to the atmosphere in 1980 in Africa (Houghton et al., 1987). This contribution was mainly driven by deforestation, and other forms of land use change like expansion of agriculture, overcultivation of existing agricultural land and extensive gathering of fuelwood. By the end of the last century, 50-70\% of West African land was under a management regime with minimal C returns to the soil (Tiessen et al., 1998). 
There is overwhelming consensus in the global climate change policy arena that mitigation actions provide the most effective $\mathrm{CO}_{2}$ emission offset (Canadell et al., 2007). One efficient way to proceed is through $\mathrm{C}$ sequestration in soils. The $\mathrm{C}$ sequestration potential under proper management of cropland globally is estimated at $0.08-0.12 \mathrm{Pg} \mathrm{yr}^{-1}$ by erosion control and $0.15-0.175 \mathrm{Pg} \mathrm{yr}^{-1}$, for example through conservation tillage (Lal and Bruce, 1999; Lal, 2004). Assuming that degraded grasslands in Senegal may be restored to woody grasslands over 20 years, then $\mathrm{C}$ sequestration rates of $0.77 \mathrm{MgCha}^{-1} \mathrm{yr}^{-1}$ may be achieved (Woomer et al., 2004a). Agroforestry simulations involving Faidherbia albida (Del.) Chev. and Leucaena leucocephala (Lam.) deWit. in Senegal also resulted in promising $\mathrm{C}$ gain $(+0.22$ and $+0.12 \mathrm{MgC} \mathrm{ha}^{-1} \mathrm{yr}^{-1}$, respectively), suggesting that improving agricultural practices is key to enhancing food production and mitigating climate change (Tschakert et al., 2004). Woody biomass $C$ was found more sensitive to longterm changes in precipitation and temperature than soil $\mathrm{C}$ (Tschakert, et al. 2004). Nonetheless, tropical deforestation averages 13 millions hectares each year, significantly contributing to emissions (Canadell et al., 2007).

\subsection{Short, medium, and long-term impact of climate change mitigation measures in West Africa}

Over $30 \%$ of $\mathrm{CO}_{2}$ emissions originate from agricultural and forestry sectors (IPCC, 2007). The Fourth Assessment Report of IPCC (2007) indicates cost effective GHG mitigation strategies in forest and agriculture sectors through improved practices, particularly in cropland grazing, rice cultivation techniques, livestock and manure management (to reduce $\mathrm{CH}_{4}$ emissions), nitrogen fertilisation (to reduce $\mathrm{N}_{2} \mathrm{O}$ emissions), irrigation efficiency; as well as restoration of cultivated peaty soils and degraded lands. Forest practices include afforestation, reforestation, forest management, and mapping land use change, water use, erosion control and soil protection. Agricultural production, including access to food, is projected to be severely compromised in many African countries with climate change. Estimates in Senegal suggest a potential decrease of $30 \%$ in plant production with climatic changes, and the potential to store $31 \% \mathrm{C}$ from improved management practices (Parton et al., 2004). By 2020 , yields from rain-fed agriculture could be reduced by up to $50 \%$ in some countries. This would further adversely affect food security and exacerbate malnutrition (IPCC, 2007). Mitigation efforts over the next 20-30 years will determine humanity's ability to achieve lower stabilization levels and avoid the worst effects of climate change (IPCC, 2007).

Technological options to increase the $\mathrm{C}$ pool in soils have to be used with reservation, since some of the practices may release $\mathrm{C}$, either due to particular environmental circumstances, or when taking into consideration other $\mathrm{C}$ pools linked to soils in order to make the global $\mathrm{C}$ budget of the ecosystem (Lal, 2004). The relationships among the main processes of loss or accumulation of soil $\mathrm{C}$ are very complex, and there are many human activities affecting them. As examples, three recommended activities - irrigation, chemical fertilization and manure application- can have drawbacks. Depending on the technology applied, the costs of pumping water, land levelling, and associated expenses can counteract the benefits of irrigation on $\mathrm{C}$ storage. Likewise, irrigation with groundwater may imply the degassing of the $\mathrm{CO}_{2}$ when taken to the surface and the subsequent precipitation of calcite in the soil, which releases $\mathrm{CO}_{2}$ (Schlesinger, 2000). Fertilization, needed to balance the stochiometric relations among organic constituents, has implicit costs of production and application that release $\mathrm{C}$ to the atmosphere, particularly when chemical. Some estimates show that biomass needs for manure production by cattle for a given surface are about 6 times the net primary production in this surface (Schlesinger, 2000). Taking this into consideration, crop residue management is more efficient than manure application.

\section{Local relevance - SOM and nutrient cycling}

\subsection{Soil quality, SOM, and ecosystem services}

According to Stewart et al. (2007), the C saturation capacity of the soil is not predetermined for each soil type, but depends strongly on the management practices of the system. These authors suggest that agroecosystems under disturbance may never attain an absolute $\mathrm{C}$ saturation level, due to accelerated OM decomposition by tillage (Fig. 3). Otherwise, the soil attainable capacity is finite, and can be filled over 20-50 years (Lal, 2004). This is of particular importance when considering strategies to improve SOC stocks, since the maximum attainment period is $5-20$ years after adoption of the recommended management practices (Lal, 2004).

Soil C, productivity, and degradative processes are closely related (Vågen et al., 2005; Roose and Bathès, 2001). C sequestration in soil provides benefits of improved soil quality (fertility, water holding capacity, resistance to erosion) and ecosystem functioning through contributions to ecosystem services: biomass production; storing, filtering and transforming nutrients and water; reducing soil temperature extremes and soil water loss; improving soil structure, water infiltration and water-holding capacity; hosting the biodiversity pool; acting as a platform for most human activities; providing raw materials; acting as $\mathrm{C}$ pool; and storing geological and archaeological heritage (Craswell and Leffroy, 2001; Table 4). As an important indicator of soil quality, SOC sequestration and conservation becomes a strategy to achieve food security (Fig. 2). Organic $\mathrm{C}$ stocks alone have been shown to describe $78 \%$ of the variability of maize yields in Nigeria (Smaling and Dixon, 2006). 
Table 4. Ecosystem services derived from soil organic carbon pool. Modified from Lal, 2004.

\begin{tabular}{|c|c|}
\hline On-site benefits & Off-site benefits \\
\hline Improvement in soil quality & Improvement of water quality \\
\hline Increase in available water capacity & Decrease in transport of pollutants \\
\hline Increase in nutrient retention & Biodegradation and denaturing of pollutants and contami- \\
\hline Improvement in soil structure and tilth & nants \\
\hline Buffering against changes in $\mathrm{pH}$ & Reduction in sediment load and siltation of water bodies \\
\hline Enhancement of soil biotic activity & Decreased in non-point source pollution \\
\hline Improvements in soil moisture and temperature regimes & Reduction in hypoxia risk in water bodies \\
\hline Increase in agronomic/forest productivity & Less damage to coastal ecosystems \\
\hline Increase in crop yield & Low risk by floods and sedimentation \\
\hline Increase in use efficiency of input (fertilizers and water) & Decrease in transport of pollutants out of the ecosystem \\
\hline \multirow{2}{*}{$\begin{array}{l}\text { Decrease in losses of soil amendments by runoff, erosion } \\
\text { and leaching }\end{array}$} & Improvement in air quality \\
\hline & Reduction in rate of enrichment of GHG \\
\hline Improvements in soil conditions & Decrease in wind-borne sediments \\
\hline Sustainability and food security & Improvement in biodiversity \\
\hline \multirow{2}{*}{$\begin{array}{l}\text { Increase in sustainable use of perturbed soil and water re- } \\
\text { sources }\end{array}$} & Increase in soil biodiversity \\
\hline & Improvement in wildlife habitat and species diversity on re- \\
\hline Food security increase & stored ecosystems \\
\hline Additional income from trading $\mathrm{C}$ credits & Improvement in aesthetic and cultural value \\
\hline \multirow{4}{*}{$\begin{array}{l}\text { Improvement in nutritional value of food and avoidance of } \\
\text { hidden hunger }\end{array}$} & Desertification control \\
\hline & Restoration of desertified lands \\
\hline & Reversal of degradation trends \\
\hline & Strengthening elemental recycling mechanisms \\
\hline
\end{tabular}

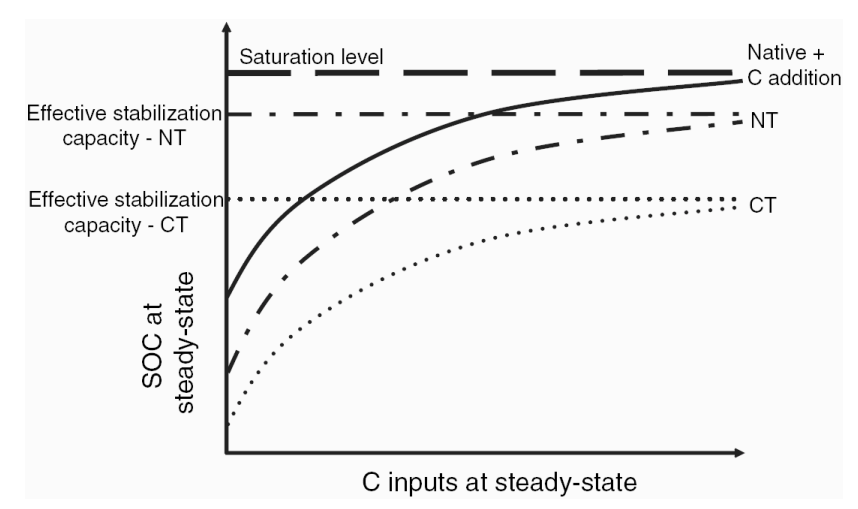

Fig. 3. Soil carbon accumulation dynamics under theoretical decomposition regimes produced by management scenarios. NT, notillage; CT, conventional tillage. Steady-state SOC content will be greater for NT than for CT under the same C input level, since NT has a reduced specific decomposition rate compared to CT. Effective stabilization capacity is the upper limit to $\mathrm{C}$ storage as a function of the different specific decomposition rates. These systems are not considered saturated due to $\mathrm{C}$ decomposition conditions dominating C stabilization. Source: Stewart et al., 2007 (copyright Springer).

\subsection{Terrestrial carbon in West Africa: management considerations with local relevance}

Management practices are being developed in West Africa that target the improvement of soil quality using soil $\mathrm{C}$ as a primary indicator of services such as productivity and erosion control. Those management practices consist of addition of high amounts of biomass to the soil, minimal soil disturbance, conservation of soil and water, improvement of soil structure, enhancement of activity and species diversity of soil fauna, and strengthening of mechanisms of elemental cycling (Table 5; Lal, 2004). Lal (2004) demonstrated potential crop yield increase by $20-40 \mathrm{~kg} \mathrm{ha}^{-1}$ for wheat, $10-20 \mathrm{~kg} \mathrm{ha}^{-1}$ for maize, and 0.5 to $1 \mathrm{~kg} \mathrm{ha}^{-1}$ for cowpea through one $\mathrm{Mg}$ increase in soil $\mathrm{C}$ pool on degraded cropland. Also, the Greening of the Sahel project in Niger (USAID) demonstrated that assisted natural regeneration (RNA) provides short-term increases in soil fertility in addition to improving the microclimate (Larwanou et al., 2007).

Restoration of degraded soils has the potential to provide terrestrial sinks of $\mathrm{C}$ and reduce the rate of enrichment of atmospheric $\mathrm{CO}_{2}$. Woomer et al. (2004a) report a study in Senegal where the terrestrial $\mathrm{C}$ stocks ranged from $9 \mathrm{MgCha}^{-1}$ in degraded savannahs in the north to $113 \mathrm{Mg} \mathrm{Cha}^{-1}$ in the remnant forests of the River Senegal valley. The results of Woomer et al. (2004a) further showed that the estimated total C stocks were $1019 \mathrm{Tg}$ in 1965 and $727 \mathrm{Tg}$ in 2000, indicating a loss of 292 MT C over 35 years. 
Table 5. Technological C-sequestration options for humid and semi-arid climates. Modified from Lal, 2004.

\begin{tabular}{|c|c|c|}
\hline Technological options & $\begin{array}{l}\text { Humid tropical } \\
\text { climate }\end{array}$ & $\begin{array}{l}\text { Semi-arid tropical } \\
\text { climate }\end{array}$ \\
\hline & \multicolumn{2}{|c|}{$\mathrm{T} \mathrm{C} \mathrm{ha}^{-1}$ year $^{-1}$} \\
\hline \multicolumn{3}{|l|}{ Cropland } \\
\hline No-till/conservation tillage & $0.2-0.5$ & $0.1-0.2$ \\
\hline Cover crops and elimination of bare fallow & $0.1-0.2$ & $0.05-0.1$ \\
\hline Manuring (10-20 $\mathrm{Mg} \mathrm{ha}^{-1}$ year $\left.^{-1}\right)$ & $0.2-0.4$ & $0.1-0.2$ \\
\hline Complex rotation with deep rooted plants & $0.1-0.2$ & $0.02-0.05$ \\
\hline Integrated pest management & $0.02-0.05$ & $0.01-0.2$ \\
\hline Irrigation and water management & - & $0.2-0.4$ \\
\hline Agroforestry & $0.2-0.5$ & $0.1-0.2$ \\
\hline Rice paddies & $0.2-0.5$ & $0.05-0.1$ \\
\hline \multicolumn{3}{|l|}{ Grazing land } \\
\hline Improved pastures & $0.5-1.0$ & $0.1-0.2$ \\
\hline Fertility management & $0.2-0.4$ & $0.05-0.1$ \\
\hline Grazing management & $0.4-0.6$ & $0.1-0.2$ \\
\hline \multicolumn{3}{|l|}{ Forest land } \\
\hline Timber harvest & $0.2-0.4$ & $0.1-0.2$ \\
\hline Site preparation & $0.1-0.2$ & $0.05-0.1$ \\
\hline Improved species & $0.4-0.8$ & $0.1-0.2$ \\
\hline Stand management & $0.1-0.2$ & $0.05-0.1$ \\
\hline \multicolumn{3}{|l|}{ Degradated soils } \\
\hline Soil erosion by water & $0.2-0.4$ & $0.1-0.2$ \\
\hline Soil erosion by wind & - & $0.05-0.1$ \\
\hline Salt affected soils & - & $0.2-0.5$ \\
\hline Mine soils & $0.2-0.4$ & $0.1-0.2$ \\
\hline Wetland restoration & $0.2-0.4$ & $0.1-0.2$ \\
\hline
\end{tabular}

Strong differences in SOM between cropland and a remnant of Sudanian forest have also been reported in the savannah region in Northern Togo (Poch and Ubalde, 2006). Woomer et al. (2004b) also showed that the total system C at $40 \mathrm{~cm}$ soil depth in the Sahel of Senegal ranged between 12.0 and $31.2 \mathrm{MgCha}^{-1}$, while the total SOC contents ranged between 11.6 and $25.3 \mathrm{Mg} \mathrm{Cha}^{-1}$.

Land degradation and nutrient mining is severe in the Sahelian countries where cereal production fell by 12.7 percent in 2000 (Pieri, 1995). The application of inorganic fertilizers is rare $\left(8 \mathrm{~kg} \mathrm{ha}^{-1}\right.$ relative to $107 \mathrm{~kg} \mathrm{ha}^{-1}$ in developing countries) and it is expected to remain low until 2030 (Tieszen et al., 2004). The SOC pool can be enhanced by the restoration of degraded soils, and the conversion to planted fallows, agroforestry, plantations, improved pastures and mulch farming (Lal, 2005). These practices are capable of sequestering $\mathrm{C}$ at a rate of $100-1000 \mathrm{~kg} \mathrm{Cha}^{-1} \mathrm{yr}^{-1}$, compared to the total potential of SOC sequestration of $200-500 \mathrm{Tg} \mathrm{C} \mathrm{yr}^{-1}$ in tropical forest ecosystems. Unruh et al. (1993) found that the types of agroforestry that included fuelwood production had the most potential to accumulate $\mathrm{C}$ in sub-Saharan Africa and estimated values of between 6 and $23 \mathrm{Pg} \mathrm{C}$, depending on the density of trees. However, if belowground biomass was included the potential for soils to accumulate $\mathrm{C}$ under agroforestry raised the estimates to between 8 and $54 \mathrm{PgC}$. The accumulation of such amount of $\mathrm{C}$ could offset global emissions from fossil fuels for 1.7 to 9 years and African emissions for 20 to 125 years (Unruh et al., 1993). Certain management practices, such as contour cropping, significantly increased SOC in several west african agrosystems (Doumbia et al, 2009). The authors attribute this increase to reduced erosion, greater rainfall capture and increased growth due to higher soil moisture. Other practices, such as cereal residue incorporation, are also effective for the mitigation of $\mathrm{C}$ loss due to agriculture (Traoré et al., 2008). The increase of crop yields due to this practice is more noticeable in the sahelian than in the sudano-guinean zone, and it is attributed partly to a lower erosion rates and faster OM decomposition of the mulch layer in the latter (Buerkert et al., 2000). It is suggested that only $20 \%$ of the croplands and $10 \%$ of 
grasslands in Africa can be subjected to improved management practices, which will result in the sequestration of 20 to $43 \mathrm{Tg} \mathrm{C} \mathrm{yr}^{-1}$ (Batjes, 2004).

The establishment of natural or improved fallow systems such as agroforestry has the potential of increasing SOC, with attainable rates of $\mathrm{C}$ sequestration in the range of 0.1 to $5.3 \mathrm{Mg} \mathrm{Cha}^{-1} \mathrm{yr}^{-1}$ (Vågen et al., 2005). Vågen et al. (2005) reported that the addition of manure in combination with crop residues and no-till cultivation can attain $\mathrm{C}$ sequestration rates of $0-0.36 \mathrm{MgCha}^{-1} \mathrm{yr}^{-1}$. They also found that that rates of $\mathrm{C}$ sequestration on permanent cropland in subSaharan Africa under improved cultivation systems (e.g. notill) range from $0.2-1.5 \mathrm{Tg} \mathrm{C} \mathrm{yr}^{-1}$, while the attainable rates under fallow systems are $0.4-18.5 \mathrm{Tg} \mathrm{C} \mathrm{yr}^{-1}$ compared to the potential rates of sequestration of $28.5 \mathrm{Tg} \mathrm{Cyr}^{-1}$ in that region. Tschakert et al. (2004) used a biogeochemical model to simulate soil and biomass $C$ over a period of 25 and 50 years that ranged between $-0.31 \mathrm{MgC} \mathrm{ha}^{-1} \mathrm{yr}^{-1}$ for a worst-case millet-sorghum rotation to $+0.43 \mathrm{MgCha}^{-1} \mathrm{yr}^{-1}$ on intensively managed agricultural fields. Furthermore, a farmercentred ex-ante cost benefit analysis of 15 management and land use options, including agroforestry, reported net benefits ranging from $-\$ 1400$ to $\$ 9600 \mathrm{Mg} \mathrm{C}^{-1}$. However, human disturbance in Senegal's Sahel Transition Zone accounted for only 22 percent of biomass C loss in 1993, suggesting that the effects of long-term Sahelian drought continue to play an overriding role in ecosystem change (Woomer et al., 2004b).

\section{Biodiversity, ecosystem services, and soil carbon in West Africa}

Biodiversity has particular relevance for $\mathrm{C}$ sequestration and conservation in tropical zones and biodiversity hotspots, one of which is the Guinean forest zone of West Africa (Mittermeier, 2004). In this context, biodiversity protection in West Africa may serve keystone or rare species, but biodiversity also maintains and restores vital ecosystem services such as commodity production and hydrological services (Fischer et al., 2006). It has been suggested that synergy between the objectives of biodiversity protection and avoided deforestation mitigation may be one potential "win-win" scenario for a diverse group of stakeholders, and thus should be a first priority for $\mathrm{C}$ mitigation in developing countries (Diaz et al., 2001).

Biodiversity is related to sustainability and resilience of ecosystems and the provision of ecosystem goods and services (MA, 2005). Though ecologists are really just beginning to understand the mechanistic effects of diversity on ecosystem function (Reich et al., 1997; Mittelbach et al., 2001; Hooper et al., 2005) there is consensus that biodiversity underlies ecosystem services (Millenium Ecosystem Assessment, 2005; Rodriguez et al., 2006.; Kirwan et al., 2007), and that with biodiversity loss ecosystem function is threatened, as well as the goods and services ecosystems pro-

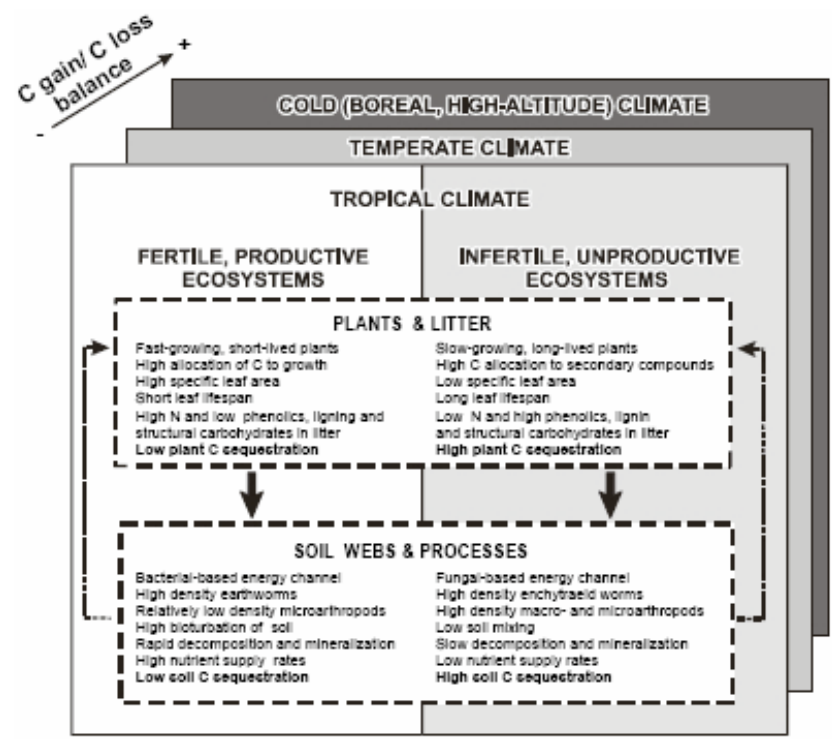

Fig. 4. The traits of dominant plants strongly influence $\mathrm{C}$ and mineral nutrient cycling and thus $\mathrm{C}$ sequestration capacity in different ecosystems. Plants traits serve as determinants of the quality and quantity of resources that enter the soil and the key ecological processes in the decomposer subsystem driven by soil biota. These linkages between belowground and aboveground systems are expected to feed back (dotted line) to the plant community positively in fertile (left) and negatively in infertile (right) ecosystems. Source: Diaz et al., 2007.

vide (Chapin et al., 1997; Loreau et al., 2001; Hooper et al., 2005). Plant functional trait and species diversity may both be compromised under a scenario of climate change (de Bello et al. 2005; Sebastià, 2007; Sebastià et al., 2008).

A relationship between soil $\mathrm{C}$ storage and species richness has been reported in experimental grassland systems (Tilman et al., 2006), in boreal forests (Hollingsworth et al., 2008), and in managed grasslands in the savannah region of Northern Togo (Sebastià et al., 2008). Previous studies on the ecosystem effects of biodiversity have used net primary productivity (NPP) as an integrated measure of ecosystem function and ecosystem service provision (Costanza et al., 2007; Kirwan et al., 2007). Of particular relevance for tropical zones is the finding by Costanza and colleagues (2007) that biodiversity showed the strongest regulating effect on productivity in high-temperature zones.

However, functional diversity may be a stronger predictor of ecosystem processes than species number (Tilman et al., 1997; de Bello et al. 2006). Dominant ecosystem plant traits directly influence $\mathrm{C}$ sequestration potential via respiration by leaves, from woody material and litter, from soil roots, and microbial respiration which is influenced by litter quality with additional subsequent effects on the process of decomposition (Fig. 4; Schulze, 2006; De Deyn et al., 2008). Thus, functional trait diversity may have an effect 
on soil C storage through processes other than productivity, including decomposition and nutrient cycling. Shifts in plant guilds and functional types have been related to soil $\mathrm{C}$ storage (Fornara and Tilman, 2008) and nutrient dynamics (Sebastià, 2007) in ecosystems.

The trait pool in West Africa is partly affected by sustained human intervention in the landscape over millennia, contributing to an observed "dominant ruderal strategy" in the distribution of vascular plants in Guinean forests associated with the toleration of open and dry conditions (Holmgren and Poorter, 2007). Human activities fracture forest and savannah ecosystems, favouring plant traits related to the colonization of open areas (Holmgren and Poorter, 2007). Changes in the plant community implies changes in the amount and quality of litter inputs to the soil, thus such shifts driven by land use can lead to low fertility and desertification (Milton and Dean, 1994; Ringius, 2002).

\section{The human footprint on SOC: management and land use in West Africa}

\subsection{Land use change and soil carbon evolution}

Deforestation in West Africa has led to increases in secondary savannahs (Badejo, 1998). Declines in soil fertility are also found as consequence of overgrazing, and management for livestock is associated with bush burning (Van der Werf, 1983; Adepetu, 1994). In particular, agriculture adds to $\mathrm{CO}_{2}$-driven climate risks because it favours $\mathrm{SOM}$ mineralization over sequestration (IPCC, 2007). Exposing the soil and breaking down soil aggregates puts SOC at the disposal of microbial activity and to the action of the atmospheric agents (Batjes and Bridges, 1992). This is the main process of liberation of $\mathrm{CO}_{2}$ due to land use changes from forest and pasture to croplands and plantations, which are known to have high consequences in terms of soil $\mathrm{C}$ loss (Fig. 5; Guo and Gifford, 2002). Within the semi-arid region of Senegal known as the groundnut basin (dominated by sandy soils), agricultural expansion from north to south has resulted in a decline in SOC and nitrogen, and continued expansion of the traditional groundnut-millet cultivation system into woodlands may within 40 years result in a loss of up to $1.1 \mathrm{~kg} \mathrm{C} \mathrm{m}^{-2}$ (Elberling et al., 2003). While soil $\mathrm{C}$ levels are smaller in the drier northern areas, the absolute values of short-term losses of soil $\mathrm{C}$ are approximately the same $\left(0.06 \mathrm{~kg} \mathrm{C} \mathrm{m}^{-2}\right.$ per year; Elberling et al., 2003). Despite the rapid losses of soil $\mathrm{C}$ in the region, the combination of modelling with land use classification estimated between $54 \mathrm{~kg} \mathrm{Cha}^{-1} \mathrm{yr}^{-1}$ may be sequestered for the study area with ridge tillage, increased application of fertilizers, and residue management. Encouragingly, this is about onethird the rate of $\mathrm{C}$ sequestration used for large-scale estimates of $\mathrm{C}$ sequestration potential in West Africa (Doraiswamy et al., 2006).

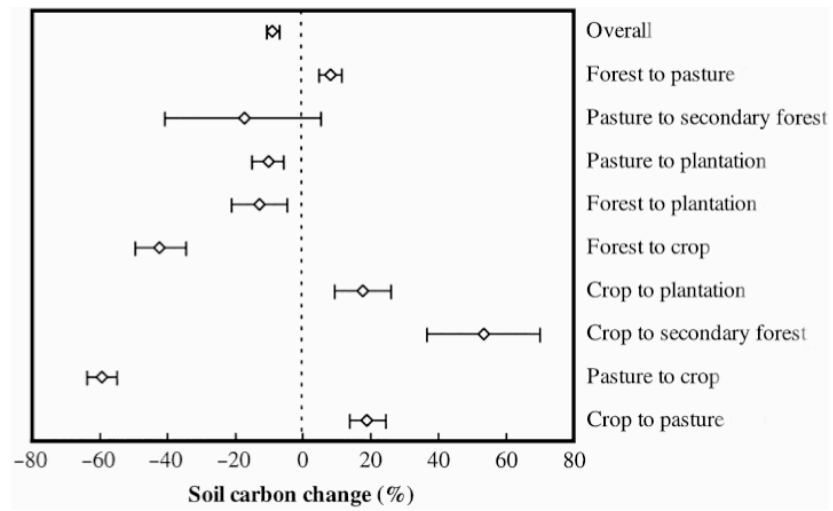

Fig. 5. Soil carbon response to variation in land use. Mean and $95 \%$ confidence intervals are shown. Source: Guo and Gifford, 2002 (copyright Blackwell Publishing).

\subsection{Fires, land degradation processes and soil carbon}

Frequent fires and over-exploitation can lead to land degradation, a major constraint to African development. It is estimated that over 500 million hectares of land have undergone soil degradation since the 1950 s which include $65 \%$ of agricultural land in Africa (GEF and IFAD, 2002). The impact of fires on SOM depends on the intensity of the fire and the distribution of SOM in depth. Although the direct effects entail a decrease of SOM and the liberation of $\mathrm{CO}_{2}$, this affects only the first centimetres of the soil, unless the fires recur with high frequency. The indirect effects in the medium and long term are, however, more important, and they can be positive for the storage of $\mathrm{C}$ (conversion of $\mathrm{C}$ of the biomass to recalcitrant forms of coal, increase of the chemical fertility in acid soils that increases their production potential) or negative (increase of erosion, reduction of infiltration). The latter (negative) is the principal effect of fire in semiarid zones, where the fires occur often in forest grounds where the organic matter is in the surface horizons, in erodible areas, and where the climate does not favor the regeneration of the forests. The light fraction of SOM $(<50 \mu \mathrm{m})$ may be comprised of up to $35 \%$ coal in soils experiencing slash and burn practices over long periods (Skjemstad et al., 2002). Soil erosion is associated with $\mathrm{C}$ emissions, although not all the implied mechanisms act in the same direction. The primary mechanisms of erosion are the liberation and transportation of the SOM by wind or water during which SOM is mineralized faster, which results in a decrease in situ of the physical, chemical and biological quality of the soil and therefore of its potential to sequester $\mathrm{C}$ (Table 6). The effects are a decrease in situ of the physical, chemical and biological quality of the soil and therefore of its potential to sequester C. However, depending on the place where the SOM is deposited the organic matter can be sequestered (sediments of lakes, reservoirs) or can be accumulated in certain soils improving their 
Table 6. Carbon deposits by rainfall, carbon losses by erosion, runoff and leaching, and carbon stock in the topsoil ( $30 \mathrm{~cm})$ under natural and cropped field conditions, in runoff plots at Adiopodoumé, Korhogo (Ivory Coast) and Saria (Burkina Faso). Source: Roose and Bathès, 2001.

\begin{tabular}{|c|c|c|c|c|c|c|}
\hline \multirow[t]{2}{*}{ Location } & \multicolumn{2}{|l|}{$\mathrm{C}$ deposits } & \multicolumn{3}{|c|}{ C losses } & \multirow{2}{*}{$\begin{array}{l}\text { C stock } \\
\text { (topsoil } 30 \mathrm{~cm}) \mathrm{kg} \mathrm{ha}^{-1}\end{array}$} \\
\hline & by rainfall $\mathrm{kg}^{-1}$ ha yr ${ }^{-1}$ & Erosion & $\begin{array}{l}\text { Runoff } \\
\mathrm{kg} \mathrm{ha}^{-}\end{array}$ & $\begin{array}{l}\text { Leaching } \\
-1 \mathrm{yr}^{-1}\end{array}$ & Total & \\
\hline \multicolumn{7}{|c|}{ Adiopodoume (2100 mm rainfall) } \\
\hline Sub-equatorial forest & 155.6 & 13.0 & 1.2 & 73.9 & 88.1 & 45670 \\
\hline Cereals & 27.3 & 1801.0 & 64.8 & 7.0 & 1872.8 & 34180 \\
\hline \multicolumn{7}{|l|}{ Korogho (1300 mm rainfall) } \\
\hline Sudanian savannah & 46.1 & 5.5 & 2.1 & 12.6 & 20.2 & 22570 \\
\hline Maize, with fertilizers & 14.9 & 64.1 & 17.6 & 2.5 & 84.2 & 20583 \\
\hline \multicolumn{7}{|l|}{ Saria (800 mm rainfall) } \\
\hline Sudano-sahelian savannah & 22.4 & 22.4 & 1.1 & 1.5 & 11.1 & 14545 \\
\hline Cereals & 11.2 & 11.2 & 5.4 & 0.3 & 115.4 & 13205 \\
\hline
\end{tabular}

quality (toeslopes, floodplains, deltas). These areas become sinks of $\mathrm{C}$ in so far as the organic matter remains there with periods of recurrence longer than those of the places where it was eroded. However, the erosion cannot be considered as a simple process of organic matter redistribution in the landscape since there are some irreversible losses by mineralization (Lal, 2001).

\subsection{Soil carbon and socio-economic structure}

Soil C preservation in West Africa, as elsewhere, depends on socio-economic structures and well-designed support policy measures. In addition, stakeholders are key agents of change towards sustainable practices enhancing $\mathrm{C}$ conservation. In Senegal, local farming systems in Old Peanut Basin have embarked on different pathways of change to adapt to their evolving environment, despite some general trends of resource degradation (Tschakert and Tappan, 2004). A study in Ghana (Sagoe, unpublished doctoral dissertation) revealed that communities with strong social ties and networks are more likely to embrace land management activities that would improve SOC, biodiversity, and livelihood. Within the studied communities, common culture and kinship were found to be enabling factors, whereas communities with weak social ties were found to be less developed and unwelcoming to innovation. In assessing the real hazards of various households (Fig. 6), most household concerns (96\%) were related to financial capital, followed by natural capital (40\%) which includes land, soil productivity and biodiversity (Sagoe, unpublished doctoral dissertation).

Gender also played a key role in land use and land use change of households in the studied communities; maleheaded households had greater access to human capital than the female-headed households. In the female-headed households, the majority of household heads were found to be single-parent divorcees, widows, or never-married persons,

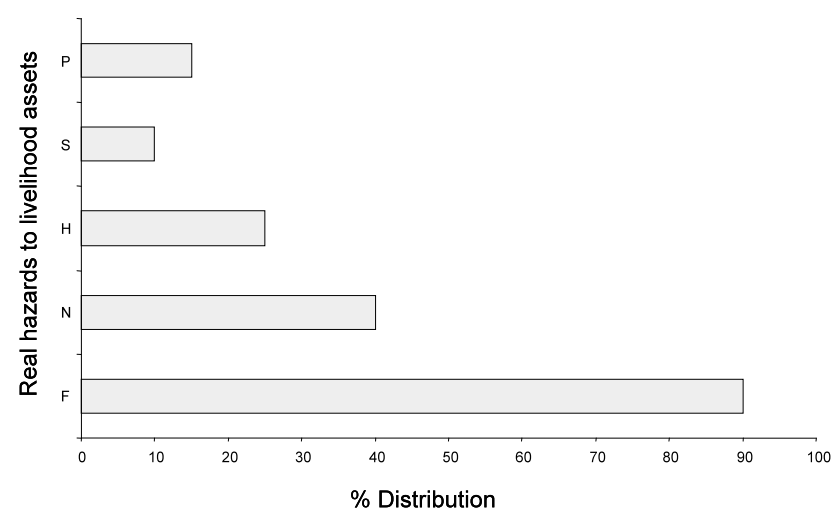

Fig. 6. Percentage distribution of real world hazards to livelihood assets. Impacts of Risks/Stressors on Types of Capital: $\mathrm{F}=$ Financial; $\mathrm{N}=$ Natural; $\mathrm{H}=$ Human; $\mathrm{S}=$ Social; $\mathrm{P}=$ Physical. Source: Sagoe, unpublished data.

and these households cannot afford the human and financial capital needed for SOC interventions (Sagoe, unpublished doctoral dissertation).

Since any factor or process that influences land use would invariably affect SOC, social issues such as gender disparity in access to land, crop grown, ethnicity, cultures and financial implications must be considered. This may only be achieved if communities are included in the early stage of development-related decision-making or activity design. A "win-win" scenario that suits the goals of a diverse group of stakeholders will not emerge easily. Other constraints such as poverty and over-exploitation of forests needed to be considered in attempts to increase $\mathrm{C}$ sequestration in West African productive ecosystems, in order to avoid inappropriate tradeoffs for food production or added social tensions or other risks (Perez et al., 2007; Tschakert et al., 2007). Participation or buy-in from local stakeholders may be the difference 
between project success and failure in the long term (Diaz et al., 2001).

\section{Concluding remarks}

The soil is the largest reservoir of $\mathrm{C}$ in the terrestrial carbon cycle. As such, understanding the spatial and temporal distribution of $\mathrm{C}$ sources and sinks in the terrestrial biosphere is crucial for countries to make informed decisions about limiting their emissions and also responding to other national development challenges like land degradation and food security. Soil scientists now recognize SOM as a major factor controlling the capacity of soil resources to deliver agricultural and environmental services and sustain human societies at both local (e.g. fertility maintenance) and global (e.g. mitigation of atmospheric $\mathrm{C}$ emissions) scales. As such, climate change mitigation programs in West Africa will have direct impacts in other sectors.

Sub-Saharan Africa has a high potential for C sequestration, largely in the opportunity to restore lands degraded by agricultural expansion, deforestation, erosion, and desertification. Strategies for soil C sequestration must be sensitive to the diversity of ecosystem types which range from Guinean rainforest to Sahelian broken savannah, and also to cultural and social factors that can either promote or hinder $\mathrm{C}$ conservation. Ethically, as well as practically, sustainable $\mathrm{C}$ sequestration policies should be built with the understanding that SOC and SOM provide important ecosystem services beyond $\mathrm{CO}_{2}$ mitigation, and therefore that local and global ecosystem service provision will covary for some services. Given the diversity of environments, global policies must be reconstituted at a national scale in order to enable improved $\mathrm{C}$ storage. The policies must act locally at the scale of the small shareholder or village, and focus on the ecosystem services rather than on $\mathrm{C}$ sequestration solely.

In essence, the need addressed here is a synthesis of the commonalities shared between global and local goals, and it is hoped that this will aid future research and policy efforts on the conservation of soil $\mathrm{C}$ and biodiversity. What is advocated is applied work that specifically seeks to pair $\mathrm{C}$ sequestration for mitigation purposes with local development issues related to soil quality. We do not expect such "win-win" scenarios to emerge easily, but we continue to believe that such opportunities should, and do, exist.

Acknowledgements. We would like to acknowledge David Solano for his assistance to make this collaborative work possible, as well as other participants of the conference, Climate, Carbon, and Cultures, held in Saly, Senegal February 2008, for enriching us with their interdisciplinary expertise related to carbon in development in West Africa. Funding from the Agencia Española de Cooperación Internacional Para el Desarrollo made the work possible.

Edited by: F. Carswell

\section{References}

Adepetu, J. A.: Soil fertility management and sustainable farming systems, National Agricultural Land Development Authority Workshop, Mena, Nigeria, 1994.

Badejo, M. A.: Agroecological restoration of savanna ecosystems, Ecol. Eng., 10, 209-219, 1998.

Bationo, A., Kihara, J., Vanlauwe, B., Waswa, B., and Kimetu, J.: Soil organic carbon dynamics, functions and management in West African agro-ecosystems, Agr. Syst., 94, 13-25, 2007.

Batjes, N. H.: Total carbon and nitrogen in the soils of the world, Eur. J. Soil Sci., 47, 151-163, 1996.

Batjes, N. H.: Options for increasing carbon sequestration in West African soils: An exploratory study with special focus on Senegal, Land Degrad. Dev., 12, 131-142, 2001.

Batjes, N. H.: Estimation of soil carbon gains upon improved management within croplands and grasslands of Africa. Environ. Dev. Sustain., 6, 133-143, 2004.

Batjes, N. H. and Bridges, E. M.: A review of soil factors and processes that control fluxes of heat, moisture and greenhouse gases. International Soil Reference and Information Centre, Wageningen, The Netherlends, 192 pp., 1992.

Brümmer, C., Papen, H., Wassmann, R., and Brüggemann, N.: Fluxes of $\mathrm{CH}_{4}$ and $\mathrm{CO}_{2}$ from soil and termite mounds in south Sudanian savannaof Burkina Faso (West Africa), Global Biochem. Cy., 23, GB1001, doi:10.1029/2008GB003237, 2009.

Buerkert, A., Bationo, A., and Dossa, K.: Mechanisms of residue mulch-induced cereal growth increases in West Africa, Soil Sci. Soc. Am. J., 64, 346-358, 2000.

Canadell, J. G., Kirschbaum, M. U., Kurz, W. A., Sanz, M. J., Schlamadinger, B., and Yamagata, Y.: Factoring out natural and indirect human effects on terrestrial carbon sources and sinks, Environ. Sci. Policy, 10, 370-384, 2007.

Chapin III, F. S., Walker, B. H., Hobbs, R. J., Hooper, D. U., Lawton, J. H., Sala, O. E., and Tilman, D.: Biotic control over the functioning of ecosystems, Science, 277, 500-504, 1997.

Costanza, R., Fisher, B., Mulder, K., Liu, S., and Christopher, T.: Biodiversity and ecosystem services: a multi-scale empirical study of the relationship between species richness and net primary production, Ecol. Econ., 61, 478-491, 2007.

Craswell, E. T. and Lefroy, R. D. B.: The role and function of organic matter in tropical soils, Nutr. Cycl. Agroecosys., 61, 7-18, 2001.

de Bello, F., Leps, J., and Sebastià, M.-T.: Predictive value of plant traits to grazing along a climatic gradient in the Mediterranean, J. Appl. Ecol., 42, 824-833, 2005.

de Bello, F., Leps, J., and Sebastià, M.-T.: Variations in species and functional plant diversity along climatic and grazing gradients, Ecography, 29, 801-810, 2006.

De Deyn, G. B., Cornelissen, J. H., and Bardgett, R. D.: Plant functional traits and soil carbon sequestration in contrasting biomes, Ecol. Lett., 11. 516-531, 2008

Diaz, S., Wardle, D. A., and Hector, A.: Incorporating biodiversity in climate change mitigation initiatives, Seasonally Dry Tropical Forest Symposium, Stanford, Palo Alto, USA, 2001.

Diaz, S., Lavorel, S., de Bello, F., Quetier, F., Grigulis, K., and Robson, T. M.: Incorporating plant functional diversity effects in ecosystem service assessments, P. Natl. Acad. Sci. USA, 104, 20684-20689, 2007. 
Doraiswamy, P. C., McCarty, G. W., Hunt, J., Yost, R. S., Doumbia, M., and Franzluebbers, A. J.: Modeling soil carbon sequestration in agricultural lands of Mali, Agr. Syst., 94, 63-74, 2006.

Doumbia, M., Jarju, A., Sène, M., Traoré, K., Yost, R., Kablan, R., Brannan, K., Berthe, A., Yamoah, C., Querido, A., Traoré, P. C. S., and Ballo, A.: Sequestration of organic carbon in West African soils by Aménagement en Courbes de Niveau, Agron. Sustain. Dev., 29, 267-275, 2008.

Elberling, B., Toure, A., Rasmussen, K.: Changes in soil organic matter following groundnut-millet cropping at three locations in semi-arid Senegal, West Africa, Agr. Ecosyst. Environ., 96, 3747, 2003.

Eswaran, H., Reich, P. F., Kimble, J. M., Beinroth, F., Padmanabhan E., and Moncharoen, P.: Global carbon stocks, in: Global climate change and pedogenic carbonates, edited by: Lal R., Kimble J. M., Eswaran H., Stewart B. H., Lewis, Boca Raton, USA, 15-26, 1999.

Eswaran, H., van den Berg, E., and Reich, P.: Organic carbon in soils of the world, Sol. Sci. Soc. Am. J., 57, 192-154, 1993.

Friedlingstein, P., Cadule, P., Piao, S. L., Ciais, P., and Sitch, S.: The African contribution to the global climate-carbon cycle feedback of the 21st century, Biogeosciences Discuss., 5, 4847-4866, 2008 , http://www.biogeosciences-discuss.net/5/4847/2008/.

GEF (Global Environment Facility), and IFAD (International Fund for Agricultural Development), Tracking land degradation and desertification, GEF and IFAD Partnership, 2002.

Giardina, C. P. and Ryan M. G.: Evidence that decomposition rates of organic carbon in mineral soil do not vary with temperture, Nature, 404, 858-861, 2000.

Guo, L. B. and Gifford, R. M.: Soil carbon stocks and land use change: a meta analysis, Glob. Change Biol., 8, 345-360, 2002.

Hien, E., Ganry, F., and Oliver, R.: Carbon sequestration in a savannah soil in southwestern Burkina as affected by cropping and cultural practices, Arid Land Res. Manag., 20, 133-146, 2006.

Holmgren, M. and Poorter, L.: Does a ruderal strategy dominate the endemic flora of the West African forests?, J. Biogeogr., 34, 1100-1111, 2007.

Hollingsworth, T. N., Schuur, E. A. G., Chapin III, F. S., and Walker, M. D.: Plant community composition as a predictor of regional soil carbon storage in Alaskan boreal black spruce ecosystems, Ecosystems, 11, 629-642, 2008.

Hooper, D. U., Chapin III, F. S., Ewel, J. J., Hector, A., Inchausti, P., Lavorel, S., Lawton, J. H., Lodge, D. M., Loreau, M., Naeem, S., Schmid, B., Setala, H., Symstad, A. J., Vandermeer, J., and Wardle, D. A.: Effects of biodiversity on ecosystem functioning: A consensus of current knowledge, Ecol. Monogr., 75, 3-35, 2005.

Houghton, R. A., Boone, R. D., Fruci, J. R., Hobbie, J. E., Melillo, J. M., Palm, C. A., Peterson, B. J., Shaver, G. R., Woodwell, G. M., Moore, B., Sloke, D. L., and Myers, N.: The flux of carbon from terrestrial ecosystems to the atmosphere in 1980 due to changes in land use: geographic distribution of the global flux, Tellus, 39(B), 122-139, 1987.

IPCC (Intergovernmental Panel on Climate Change): Climate change 2007: impacts, adaptation and vulnerability: Working Group II contribution to the Fourth Assessment Report of the IPCC Intergovernmental Panel on Climate Change, IPCC Secretariat, 1000 pp., 2007.
Jenik, J.: The Dahomey gap: an important issue in african phytogeography, Memoirs of the Society for Biogeography, 3, 125133, 1994.

Jordan C. F.: Productivity of tropical rain forest ecosystems and the implications for their use as future wood and energy sources, in: Tropical rain forest ecosystems, edited by: Golley F. B., Lieth H., Werger M. J. A., Elsevier Scientific Pub. Co., New York, USA, 117-132, 1983.

Kirschbaum, M. U. F.: The temperature dependence of soil organic matter, and the effect of global warming on soil organic $\mathrm{C}$ storage, Soil Biol. Biochem. 27, 753-760, 1995.

Kirwan, L., Luescher, A., Sebastià, M.-T., Finn, J. A., Collins, R. P., Porqueddu, C., Helgadottir, A., Baadshaug, O. H., Brophy, C., Coran, C., Dalmannsdottir, S., Delgado, I., Elgersma, A., Fothergill, M., Frankow Lindberg, B. E., Golinski, P., Grieu, P., Gustavsson, A. M., Hoglind, M., Huguenin Elie, O., Iliadis, C., Jorgensen, M., Kadziuliene, Z., Karyotis, T., Lunnan, T., Malengier, M., Maltoni, S., Meyer, V., Nyfeler, D., Nykanen, K. P., Parente, J., Smit, H. J., Thumm, U., and Connolly, J.: Evenness drives consistent diversity effects in intensive grassland systems across 28 European sites, J. Ecol., 95, 530-539, 2007.

Lal, R. and Bruce, J. P.: The potential of world cropland soils to sequester $\mathrm{C}$ and mitigate the greenhouse effect, Environ. Sci. Pol., 2, 177-185, 1999.

Lal, R.: Potential of desertification control to sequester carbon and mitigate the greenhouse effect, Clim. Change, 51, 35-72, 2001.

Lal, R.: The potential of soils of the tropics to sequester carbon and mitigate the green house effect, Adv. Agron., 76, 1-30, 2002.

Lal, R.: Global potential of soil carbon sequestration to mitigate the greenhouse effect, Crit. Rev. Plant Sci., 22, 151-184, 2003.

Lal, R.: Soil carbon sequestration impacts on global climate change and food security, Science, 304, 1623-1627, 2004.

Lal, R.: Soil carbon sequestration in natural and managed tropical forest ecosystems, J. Sustainable Forestry, 21, 1-30, 2005.

Larwanou, M., Abdoulaye, M., and Reij, C.: Etude de la régénération naturelle assistée dans la région de Zinder (Niger), USAID/EGAT, IRG, Washington, USA, 56 pp., 2006.

Latham, M. and Dugerdil, M.: Contribution à l'étude de l'influence du sol sur la végétation au contact forêt-savane dans l'ouest et le centre de la Côte d'Ivoire, Adansonia, 2, 553-576, 1970.

Liu, S., Kaire, M., Wood, E., Diallo, O., and Tieszen, L. L.: Impacts of land use and climate change on carbon dynamics in southcentral Senegal, J. Arid. Environ., 59, 583-604, 2004.

Loreau, M., Naeem, S., Inchausti, P., Bengtsson, J., Grime, J. P., Hector, A., Hooper, D. U., Huston, M. A., Raffaelli, D., Schmid, B., Tilman, D., and Wardle, D. A.: Biodiversity and ecosystem functioning: current knowledge and future challenges, Science, 294, 804-808, 2001.

Millennium Ecosystem Assessment: Ecosystems and human wellbeing, Island Press, Washington DC, USA, 137 pp., 2005.

Milton, S. J. and Dean, W. R.: A conceptual model of arid rangeland degradation, Bioscience, 44, 70-76, 1994.

Mittelbach, G. G., Steiner, C. F., Scheiner, S. M., Gross, K. L., Reynolds, H. L., Waide, R. B., Willig, M. R., Dodson, S. I., and Gough, L.: What is the observed relationship between species richness and productivity?, Ecology, 82, 2381-2396, 2001.

Mittermeier, R. A.: Hotspots revisited, Cemex, Mexico City, Mexico, 392 pp., 2004. 
Niasse, M., Afouda, N., and Amani, A.: Reducing West Africa's vulnerability to climate impacts on water resources, wetlands and desertification. Elements for a regional strategy for preparedness and adaptation, IUCN-The World Conservation Union, 66 pp., 2004.

Palm, C. A., Myers, R. J. K., and Nandwa, S. M.: Combined use of organic and inorganic nutrient sources for soil fertility maintenance and replenishment, in: Replenishing soil fertility in Africa, edited by: Buresh R. J., Sanchez P. A., Calhoun F., SSSA, Spec. Pub. 51. Madison, WI, SSSA, 47-61, 1997.

Parton, W., Tappan, G., Ojima, D., and Tschakert P.: Ecological impact of historical and future land-use patterns in Senegal, J. Arid Environ, 59, 605-623, 2004.

Paustian, K., Andrén, O., Janzen, H. H., Lal, R., Smith, P., Tian, G., Tiessen, H., Van Noordwijk, M., and Woomer, P. L.: Agricultural soils as a sink to mitigate $\mathrm{CO}_{2}$ emissions, Soil Use Manage., 13, 230-244, 1997.

Perez, C., Roncoli, C., Neely, C., and Steiner, J. L.: Can carbon sequestration markets benefit low-income producers in semi-arid Africa? Potentials and challenges, Agr. Syst., 94, 2-12, 2007.

Pieri, C.: Long-Term Soil Management Experiments in Semiarid Francophone Africa. RC Press, Boca Raton, FL, USA, 225-266, 1995.

Poch, R. M. and Ubalde, J. M.: Diagnostic of degradation processes of soils from northern Togo (West Africa) as a tool for soil and water management, Workshop IC-PLR 2006, 2006.

Raupach, M. R., G. Marland, P. Ciais, C. Le Quéré, J. G. Canadell, and C. B. Field.: Global and Regional drivers of accelerating CO2 emissions. P. Natl. Acad. Sci. USA, 104(24), 10288-10293, 2007.

Reich, P., Walters, M. B., and Ellsworth, D. S.: From tropics to tundra: Global convergence in plant functioning, P. Natl. Acad. Sci. USA, 94, 13730-13734, 1997.

Ringius, L.: Soil carbon sequestration and the CDM: Opportunities and challenges for Africa, Clim. Change, 54, 471-495, 2002.

Rodriguez, J. P., Beard, T. D., Bennett, E. M., Cumming, G. S., Cork, S. J., Agard, J., Dobson, A. P., and Peterson, G. D.: Tradeoffs across space, time, and ecosystem services, Ecol. Soc., 11(1), art. no. 28, 2006.

Roose, E. and Bathes, B.: Organic matter management for soil conservation and productivity restoration in Africa: a contribution from Francophone research, Nutr. Cycl. Agroecosys., 61, 159170, 2001.

Rustad, L. E., Campbell, J. L., Marion G. M., Norby, R. J., Mitchell, M. J., Hartley, A. E., Cornelissen, J. H. C., and Gurevitch J.: A meta-analysis of the response of soil respiration, net nitrogen mineralization, and aboveground plant growth to experimental ecosystem warming, Oecologia 126, 543-562, 2001.

Schlesinger, W. H.: Carbon sequestration in soils: some cautions amidst optimism, Agr. Ecosyst. Environ., 82, 121-127, 2000.

Schulze, E. D.: Biological control of the terrestrial carbon sink, Biogeosciences, 3, 147-166, 2006,

http://www.biogeosciences.net/3/147/2006/.

Sebastià, M.-T.: Plant guilds drive biomass response to global warming and water availability in subalpine grassland, J. Appl. Ecol., 44, 158-167, 2007.

Sebastià, M.-T., Kirwan, L., and Connolly, J.: Strong shifts in plant diversity and vegetation composition in grassland shortly after climatic change, J. Veg. Sci., 19, 299-306, 2008.
Sebastià, M.-T., Marks, E., and Poch, R. M.: Soil carbon and plant diversity distribution at the farm level in the savannah region of Northern Togo (West Africa), Biogeosciences Discuss., 5, 41074127, 2008, http://www.biogeosciences-discuss.net/5/4107/2008/.

Skjemstad, J. O., Reicosky, D. C., Wilts, A. R., and McGowan, J. A.: Charcoal carbon in US agricultural soils, Sol. Sci. Soc. Am. J., 66, 1249-1255, 2002.

Smaling, E. and Dixon, J.: Adding a soil fertility dimension to the global farming systems approach, with cases from Africa, Agr. Ecosyst. Environ., 116, 15-26, 2006.

Stewart, C. E., Paustian, K., Conant, R. T., Plante, A. F., and Six, J.: Soil carbon saturation: concept, evidence and evaluation, Biogeochemistry, 86, 19-31, 2007.

Thornley, J. H. M. and Cannell, M. G. R.: Soil carbon storage response to temperature: an hypothesis, Ann. Bot.-London, 87, 591-598, 2001.

Tiessen, H., Feller, C., Sampaio, E. V. S. B., and Garin, P.: Carbon sequestration and turnover in semiarid savannas and dry forest, Clim. Change, 40, 105-117, 1998.

Tieszen, L. L., Tappan, G. G. and Touré, A.: Sequestration of carbon in soil organic matter in Senegal: an overview, J. Arid Environ., 59, 409-425, 2004.

Tilman, D., Wedin, D., and Knops, J.: Productivity and sustainability influenced by biodiversity in grassland ecosystems, Nature 379, 718-720, 1996.

Tilman, D., Hill, J., and Lehman, C. L.: Carbon-negative biofuels from low-input high-diversity grassland biomass, Science, 314, 1598-1600, 2006.

Traoré, P. C. S., Bostick, W. M., Jones, J. W., Koo, J., Goïta, K., and Bado, B. V.: A simple soil organic model for biomass data assimilation in community-level carbon contracts, Ecol. Appl., 18, 624-636, 2008.

Trumbore, S. E.: Potential responses of soil organic carbon to global environmental change, P. Natl. Acad. Sci. USA, 94, 8284-8291, 1997.

Tschakert, P.: Environmental services and poverty reduction: options for smallholders in the Sahel, Agr. Syst., 94, 75-86, 2007.

Tschakert, P., Khouma, M., and Sene, M.: Biophysical potential for soil carbon sequestration in agricultural systems of the Old Peanut Basin of Senegal, J. Arid. Environ., 59, 511-533, 2004.

Tschakert, P. and Tappan, G.: The social context of carbon sequestration: considerations from a multi-scale environmental history of the Old Peanut Basin of Senegal, J. Arid Environ., 59, 535564, 2004

UNEP (United Nations Environment Programme): Global environment outlook: environment for development, United Nations Environment Program Office, Nairobi, 2007.

Unruh, J. D., Houghton, R. A., and Lefebvre, P. A.: Carbon storage in agroforestry: an estimate for sub-Saharan Africa, Climate Res., 3, 39-52, 1993.

Vagen, T. G., Lal, R., and Singh, B. R.: Soil carbon sequestration in sub-Saharan Africa: a review, Land Degrad. Dev., 16, 53-71, 2005.

Van der Werf, E. J.: Ecologically sustainable agriculture as an effective means to combat desertification in tropical Africa: the case of agriculture in Accra Plains (Ghana). Stichting Mondiaal Alternatief, Zandvoort, 25 pp., 1983.

White, F.: Vegetation of Africa: a descriptive memoir to accom- 
pany the UNESCO/AETFAT/UNSO vegetation map of Africa, UNESCO, 356 pp., 1983.

Woomer, P. L., Tieszen, L. L., Tappan, G., Toure, A., and Sall, M.: Land use change and terrestrial carbon stocks in Senegal, J. Arid. Environ., 59, 625-642, 2004a.

Woomer, P. L., Touré, A., and Sall, M.: Carbon stocks in Senegal's Sahel Transition Zone, J. Arid Environ., 59, 499-510, 2004 b.
Zech, W., Senesi, N., Guggenberger, G., Kaiser, K., Lehmann, J., Miano, T. M., Miltner, A., and Schroth, G.: Factors controlling humification and mineralization of soil organic matter in the tropics, Geoderma, 79, 117-162, 1997. 